\title{
MALAPPORTIONMENT OF REPRESENTATION IN THE NATIONAL DIET
}

\author{
Hiroyuki Hata* \\ I

\section{INTRODUCTION}

Malapportionment of Diet seats is one of the most serious problems confronting contemporary Japan. After World War II, there was a large-scale population shift from rural to urban areas in Japan, as in other industrialized countries. However, the postwar statutes for apportionment of Diet members have not been fully revised to reflect this shift. This situation exists because the conservative Liberal Democratic Party and its predecessors, which have received their main support in the rural areas, have been in power ever since the war's end, except for a short period during which the Japan Socialist Party led the government. In the early 1960s, many Japanese people began to question the degree of malapportionment, and some concluded that it had passed the bounds of tolerance. At this time, the United States Supreme Court handed down its celebrated decision in Reynolds $v$. Sims ${ }^{1}$ which established the principle of "one person, one vote." This decision undeniably helped ignite public sentiment in Japan for fair and just representation in the National Diet. Since the Diet did not fully respond to this demand, the people inevitably turned to the judiciary for improvement of the situation. Lawsuits have since been filed one after another in an effort to realize the electoral equality guaranteed by the Constitution. Yet, the present situation is still far from satisfactory.

II

The Constitution and an Overview of Developments in Apportionment Law

Under the Constitution, apportionment and districting are expressly within the discretion of the National Diet, which consists of the House of Representatives and the House of Councillors. The Constitution provides that "[ $t]$ he number of the members of each House shall be fixed by law" 2 and that "[e]lectoral districts, method of voting and other matters pertaining to

\footnotetext{
Copyright (C) 1990 by Law and Contemporary Problems

- Dean and Professor of Law, Faculty of Law, Hiroshima University.

1. 377 U.S. 533 (1964).

2. 1947 Const. art. 43(2).
} 
the method of election of members of both Houses shall be fixed by law." 3 The number of members of the House of Representatives and that of the House of Councillors were first prescribed in 1947 by two statutes: the Revised Election Act for Members of the House of Representatives ${ }^{4}$ and the Election Act for Members of the House of Councillors. ${ }^{5}$ These two laws, however, were replaced in $\mathbf{1 9 5 0}$ by the Public Officials Election Act, ${ }^{6}$ which provides in Schedule I for the number of Representatives and in Schedule II for the number of Councillors. The Public Officials Election Act made slight changes in the number of members of the House of Representatives because of demographic population shifts already evident at the time of enactment.

To determine apportionment of the House of Representatives, the nation was first divided into 117 electoral districts, each of which was allocated three to five seats. The computation was made on the basis of 150,000 electors per Representative in accordance with the National Census of April 26, 1946. The rumber of Representatives was fixed at 466, a number which had not changed since 1925. As to the apportionment of the House of Councillors, the total number of its members was fixed first at 250 , then at 252 after the reversion of the Ryukyu Islands to Japan in 1972. Out of this number, 100 were elected at large, with the nation as a whole forming a single electoral district, and 150 (152 after 1972) were elected from all the prefectures, with each prefecture comprising a local electoral district. The original method of election for the members of the House of Councillors to be elected at large called for electors to cast their votes for the individual candidates of their choice. In 1982, however, this method was replaced by a form of proportional representation, ${ }^{7}$ according to which electors cast their votes for the list of candidates submitted by each political party. Seats are allocated to the candidates of the various parties in proportion to the votes they have acquired.

The apportionment of members of the House of Councillors to be elected from local electoral districts was made on the basis of 487,417 persons per Councillor, a number based on the population of Japan as of April 26, 1946, divided by 150 . However, since the members of the House of Councillors were to serve six-year terms of office, and half the House was to stand for election every three years, ${ }^{8}$ every prefecture, however small in population, was allocated at least two seats. Therefore, there was from the beginning an imbalance of 1 to 2 in the ratio of population per Councillor between the most populated district and the least populated district.

3. Id. art. 47.

4. Shugiin-giin Senkyo Hō nō Ichibu o Kaisei suru Hôritsu, Law No. 43, 1947 (amending the Election Law for Members of the House of Representatives).

5. Sangiin-giin Senkyo Hō (Election Law for Members of the House of Councillors), Law No $11,1947$.

6. Koshoku Senkyo Hō (Public Officials Election Act), Law No. 100, 1950.

7. Law No. 81, 1982 (amending Public Officials Election Act).

8. 1947 Const. art. 46. 
Thus, the apportionment of both Houses was made on the basis of the population of the electorate derived from the National Census of April 26, 1946. Moreover, Schedule I of the Public Officials Election Act makes special provision for the apportionment of members of the House of Representatives and states that "[i]t is to be made a practice to correct this Schedule in accordance with the results of the most recent National Census every five years from the date of its enforcement."

After 1946, the rural population began to move, and still continues to move, to cities in large numbers as Japan's industry develops. For this reason, the relative difference in the ratio of voters per Diet member between the rural areas and the big cities has been growing, but the National Diet has failed to make an all-out effort to correct the situation. In the case of the House of Representatives, there have been only three reapportionment statutes. The first reapportionment was in July $1964,{ }^{9}$ resulting in an increase of nineteen members, which barely reduced the disparity in the ratio of the number of the electorate per Representative to 1 to 2 . This, however, proved to be nothing but a temporary solution. In fact, according to the 1970 National Census, the relative difference between the Third District of Osaka, which was the most populous district, and the Fifth District of Hyogo, the least populous one, had reached a ratio of 1 to 4.99 .

The second reapportionment plan was put into effect in July $1975 .^{10}$ It added twenty more seats in the House of Representatives, yet the disparity that existed between the Fourth District of Chiba and the Fifth District of Hyogo was still at 1 to 3.7. This disparity was the result of the Diet's long negligence in making a decisive move toward correcting the imbalance. What the Diet had done instead to that point was simply to create and allocate some seats to extremely disadvantaged districts. This approach avoided the true problem, however, because the Diet had not tried to deprive rural constituencies, which were overrepresented in the Diet, of their excessive seats.

On April 14, 1976, Japan's Supreme Court declared unconstitutional the rules of apportionment for the members of the House of Representatives at the time of the general election of 1972, when the maximum relative difference between electoral districts in the value of each vote was 1 to 4.99. Despite its ruling of unconstitutionality, however, the Court vacated the petition for invalidation of the election itself." ${ }^{11}$ Again, on November 7, 1983, the Supreme Court hinted that, after a reasonable period of time (which the Court thought to be five years) had elapsed, it would declare unconstitutional the rules of apportionment revised according to the National Census of 1975, under which the maximum disparity had reached the level of 1 to $3.94 .^{12}$

9. Law No. 132, 1964 (amending the Public Officials Election Act).

10. Law No. 63, 1975 (amending Public Officials Election Act).

11. Kurokawa v. Chiba Prefecture Election Comm'n, 30 Minshū 223 (Sup. Ct., G.B., Apr. 14, 1976).

12. Tokyo Metropolitan Election Comm'n v. Koshiyama, 37 Minshū 1243 (Sup. Ct., G.B., Nov. 7, 1983) (reversing 984 Hanrei Jihō 26 (Tokyo H. Ct., Dec. 23, 1980). 
Those decisions forced the Diet to revise the rules of apportionment a third time. ${ }^{13}$ The new apportionment plan was called the plan of "eight plus, seven minus," for it allocated one seat each to eight districts, which were intolerably underrepresented, and deprived seven districts, which were overrepresented, of one seat each. With this revision, the traditional electorate system, with three to five members allocated per constituency, ${ }^{14}$ underwent a partial change, and brought about four two-member districts and one six-member district.

With respect to the apportionment of the members of the House of Councillors to be elected from local districts, the relative difference in the value of a vote between electoral districts had exceeded constitutionally tolerable limits, just as in the case of the House of Representatives. On February 5, 1964, however, the Supreme Court upheld the constitutionality of Schedule II of the Public Officials Election Act at the time of the 1962 election, in which the maximum disparity between districts had reached a level of approximately 1 to 4.15 Later, in April 1983, the Supreme Court again declared valid the rules of apportionment at the time of the 1977 election, in which the maximum difference had been 1 to 5.26.16 The Court looked to the peculiarities and uniquenesses of the House of Councillors to uphold the constitutionality of Schedule II, even though the disparity between districts was more than that which existed in Schedule I for the House of Representatives. The Diet has yet to make any attempt to correct electoral imbalances in the House of Councillors.

\section{III}

\section{Malapportionment of Diet Seats and Justiciability: Koshiyama V. Chatrman, Tokyo Metropolitan Election Commission}

The Japanese Supreme Court first adjudicated the constitutionality of the apportionment of Diet members in its Grand Bench decision of February 5, 1964, Koshiyama v. Chairman, Tokyo Metropolitan Election Commission. ${ }^{17}$ In the election for members of the House of Councillors held on July 1, 1962, only four members were elected from the Tokyo Metropolitan District, which had a population of 5,922,100 voters, while one member was elected from the Tottori District, with a population of only 362,182 voters. The petitioner filed suit in the Tokyo High Court, challenging the validity of the 1962 election on the grounds that the disparity between the two districts in the ratio of electoral population per Councillor was 1 to 4.09 , and that this disparity violated the Constitution. According to the petitioner, the election violated

13. Law No. 67, 1986 (amending Public Officials Election Act).

14. Amami Oshima is now the only single-member district. See Public Officials Election Act, ByLaw No. 10.

15. Koshiyama v. Tokyo Metropolitan Election Comm'n, 18 Minshū 270 (Sup. Ct., G.B., Feb. 5, 1964).

16. Shimizu v. Osaka Election Comm’n, 37 Minshū 345 (Sup. Ct., G.B., Apr. 27, 1983)

17. 18 Minshū 270 . 
Article 14, section 1, which guarantees the principle of equality under law; Article 44 (proviso), which prohibits irrational restrictions on the right to vote; and Article 15, section 3, which guarantees universal suffrage. Since the high court did not agree, the petitioner appealed to the Supreme Court, which held, first, that the proportion of the voting population to a Diet member was not the single absolute standard to be considered in determining the apportionment of the Diet, although it was a main one. Second, the Court held that the apportionment of Diet seats was within the province of the Diet's discretionary powers, except in cases where malapportionment created extreme inequality in the enjoyment of the right to vote; therefore, the apportionment could not be deemed to violate the constitutional requirement of equality under law solely because it was not in proportion to the voting population. Finally, the Court held that the maximum disparity of 1 to 4.09 between electoral districts was not unconstitutional. ${ }^{18}$

The significance of this decision was that, while declaring that the apportionment of Diet seats was a matter of legislative policy, the Court proclaimed the issue to be justiciable in cases where an extreme inequality in the voter's enjoyment of the right to vote had been created. Most constitutional lawyers in Japan evaluated the Court's stance with some reservation for not having resorted to the "political question" doctrine. They were critical, however, of the Court's interpretation that the maximum disparity of 1 to 4.09 between electoral districts in the value of a vote was not unconstitutional. The Court had undeniably been much influenced in this case by the Reynolds $v$. Sims decision, handed down in 1964 by the United States Supreme Court. ${ }^{19}$

18. The Court noted that:

[T] he Constitution does not make special provision for the number of members in both Houses, electoral districts and other matters pertaining to elections, but leaves these matters to be fixed by law, for determination of matters with respect to elections is in principle left to the discretionary powers of the National Diet. . . Neither Article 14 nor Article 44 nor any other provision in the Constitution explicitly requires the number of Diet members to be allocated in proportion to the number of electors in each district.

It is desirable, under the constitutional principle of equality under law, to allocate Diet seats to each electoral district in proportion to the number of electors, and even though it is undeniable that the proportion of the number of electors is a main factor to be considered in apportioning Diet seats to an electoral district, it is also permissible to take other factors into account. For example, under the system of electing half the members of the House of Councillors every three years under Article 46 of the Constitution, it is difficult to reduce the minimum number of two Councillors per district, however small the population of electors in a district might be. In addition, such factors as the size of an electoral district, its historical background, a balance in the number of Councillors between administrative districts, etc., for example, are also worth considering, and it is not irrational to take them into account in determining the allocation of Diet seats. . . Even if the inequality was created due to the failure to revise Schedule II of the present Public Officials Election Act in proportion to the number of electors, the inequality as it now stands still remains a matter of propriety, not a matter of constitutionality.

Id. at 272-73.

19. 377 U.S. 533. 


\section{Apportionment and the Constitutional Requirement of EQUality UNDER LAW: KUROKAWA V. CHIBA ELECTION COMMISSION}

The Japanese Supreme Court's first decision on the constitutionality of Schedule I of the Public Officials Election Act, which provided for the apportionment of members of the House of Representatives, is the Grand Bench Decision of April 14, 1976, Kurokawa v. Chiba Election Commission. ${ }^{20}$ In Kurokawa, the petitioner was a voter in the First District of Chiba who filed suit in the Tokyo High Court, contending that, since the maximum relative difference between electoral districts in the value of a vote had reached 1 to 4.99 , the rules of apportionment at the time of the election of December 10 , 1972, violated Articles 14, 15, and 44 of the Constitution, and that the election was therefore invalid. The Tokyo High Court, relying on the Supreme Court Grand Bench decision of 1964 concerning the rules of apportionment for members of the House of Councillors, held that (1) the apportionment and districting were constitutionally left to the discretion of the Diet; (2) the apportionment could not be said to violate the principle of equality under law solely on the ground that it was not in proportion to the number of voters, except in cases where extreme inequality in the enjoyment of the voter's right to vote had been created; and (3) the imbalance in the ratio of the voting population per Representative at the time of the 1972 election had not reached a constitutionally intolerable degree. Consequently, the high court dismissed the suit.

On appeal, the Supreme Court, recognizing electoral equality as a constitutional requirement, held that the apportionment and districting for members of the House of Representatives were unconstitutional in their entirety at the time of the 1972 election, for, although the maximum relative difference in the value of a vote between districts had exceeded the permissible limits of the Diet's discretion, they had not been revised within a reasonable period of time as demanded by the Constitution. The Court further held that, although the election at issue in the present case was based on unconstitutional apportionment and was invalid, the petition for invalidation of the election was denied because the general principle of law implied in the Administrative Case Litigation $\mathrm{Act}^{21}$ authorized the court to preserve defective administrative acts if it found that great harm to the public interest would result if the act were invalidated. ${ }^{22}$

20. 30 Minshū 223.

21. Gyosei Jiken Sosho Hō (Administrative Case Litigation Act), Law No. 1139, 1963, art. 31, $\S 1$. A decision based on Article 31, section 1, is called a Jijo-Hanketsu or "circumstance decision," for it considers the degree of damage a plaintiff suffers, the method of reparations to be taken, prevention of further damage, and all other circumstances.

22. The Court stated:

The principle of equality under law provided for in Article 14, section 1 of the Constitution requires, with respect to the right to vote, that all people have perfect political equality. It is proper to interpret such provisions as Article 15, section 1, etc., to not only 
This decision made clear that electoral equality was a constitutional requirement and that the maximum relative difference between districts of 1 to 4.99 in the ratio of the electoral population per Representative was unconstitutional. However, the Court held that, even if the disparity in the value of a vote between districts was acknowledged to have exceeded the bounds of the Diet's discretion, the apportionment rules would not be unconstitutional for that reason alone. They would be unconstitutional only if they had not been revised within a reasonable period of time. It is noteworthy, too, that the Court, while declaring the election invalid as based on the unconstitutional rules of apportionment, also vacated the petition to nullify that election by resorting to the technique of the "circumstance decision"'23 provided for in Article 31, section 1, of the Administrative Case Litigation Act.

prohibit discrimination in the qualification of voters, but also to require equality in the content of the right to vote, namely, to require the consideration of the value of each citizen's right to vote. ...

The rules of apportionment should not be rendered unconstitutional only because the difference of the ratio is in violation of electoral equality. It is only permissible to interpret [the rules] as unconstitutional when [the rules have] not been revised in the light of demographic shifts within a reasonable period of time demanded by the Constitution. . .

When we see the rules of apportionment at issue in the present case from this point of view, we can comprehend that a remarkable imbalance in the ratio of electoral population per Representative under them had arisen due to the gradual shifts of the population, and that, judging from the above-mentioned difference in the ratio which existed at the time of the election in the present case, the imbalance had, long before the election, reached a degree which was presumed to violate the constitutional requirement of electoral equality.

Considering that this law had nevertheless not been revised for eight years from the date of the 1964 revision to the time of the election . . ., we have to admit that the revision was not made within a reasonable period of time as demanded by the Constitution. Therefore, the rules of apportionment in the present case should have been declared unconstitutional because they violated the constitutional requirement of electoral equality at the time of the election. ...

With respect to the rules of apportionment in the present case, then, they are unconstitutional, and, therefore, the election held based on them does not conform with the constitutional requirement, as mentioned above. However, even if the rules of apportionment and the election based thereupon are interpreted as being invalid, this does not immediately bring about a constitutionally invalid situation, but rather the result is that all Representatives elected at the election will be disqualified from the beginning. This will, as a consequence, not only render of questionable validity those laws and other acts made by the resolution of the House of Representatives, which consists of those Representatives, but even leaves the House of Representatives incapable of revising legislation that has been declared unconstitutional. This is clearly a situation the Constitution does not anticipate.

It must be considered that the Administrative Case Litigation Act, a general procedural law for suits contesting the validity of administrative acts, provides in ... Article 31, section 1 that, even if administrative acts are defective, the Court may choose not to invalidate them in cases where it is deemed gravely harmful to the public interest in light of certain situations. This provision, which was enacted on the basis of a legislative policy, is also thought to contain elements to be understood as based on general principles of law which do not confine it to cases of invalidation of administrative acts.

Relying on the spirit of the above-mentioned provision, we find it proper to vacate the appeal for invalidation of the election itself, and only declare it invalid in the text of the judgment, although the election at issue is invalid because it was held on the basis of rules of apportionment which violated the Constitution.

30 Minshū at 243, 248-54.

23. See supra note 21 . 
The Grand Bench decision of 1976 is still a leading case among reapportionment cases in Japan. Although Schedule I of the Public Officials Election Act was revised in 1975, the maximum relative difference at that time in the ratio of the number of electors per Representative between districts was 1 to 2.92 , because the revision was made according to the 1970 National Census. When the election for members of the House of Representatives was held in June 1980, the discrepancy had reached a level of 1 to 3.94 . Concerning the validity of the 1980 election, the Supreme Court, on November 7, 1983, held as follows:

(1) It is acknowledged that the inequality which was found by the Grand Bench Decision of 1976 to exist at the time of the 1972 election had not been corrected;

(2) judging from the fact that the election at issue for members of the House of Representatives was held about five years after the promulgation, and three and one-half years after the enforcement of the revised law, we must say it is difficult to conclude that the revision to correct the inequality had not been made within a reasonable period of time as demanded by the Constitution; and

(3) the petition to nullify the election is therefore vacated. ${ }^{24}$

This decision implies that the Supreme Court of Japan considers the permissible limits of the imbalance in the value of a vote to be a 1 to 3 ratio and the "reasonable period" for correcting the imbalance to be five years. In sum, the Grand Bench decision of 1983 suggests that, although the maximum disparity of 1 to 3.94 between districts was in a "state of unconstitutionality," a reasonable period of time for correcting the imbalance had not yet elapsed, and therefore, the rules of apportionment on which the election at issue was based could not be judged unconstitutional.

Of six Justices who dissented in this decision, Justices Nakamura, Taniguchi, and Yasuoka took the view that a maximum disparity of 1 to 3 at the time of election was the permissible limit of imbalance, ${ }^{25}$ while Justices Dando and Yokoi thought a disparity of 1 to 2 was the maximum allowable limit. ${ }^{26}$ All of them, however, agreed that the petition to nullify the election should have been vacated according to the spirit of Article 31 , section 1 of the Administrative Case Litigation Act, even though the election based on the unconstitutional apportionment rules was invalid. Also, all those who

24. 37 Minshū 1243.

25. Id. at 1278 (Nakamura, J., dissenting); id. at 1303 (Yasuoka, J., dissenting). At that time, Justice Taniguchi did not clearly state that 1 to 3 was the permissible limit of the imbalance, but expressly said so in his dissenting opinion in Kanao v. Hiroshima Election Comm'n, 39 Minshū 1100, 1131 (Sup. Ct., G.B., July 17, 1985).

26. 37 Minshū at 1270 (Dando, J., dissenting); id. at 1289 (Yokoi, J., dissenting). While Professor Ashibe, Japan's leading constitutional law scholar, has been insisting that 1 to 2 is the maximum allowable limit under the Constitution, Ashibe, Gi in Teisu Haibun Kitei Iken Hanketsu no Igi to Mondaiten (Significance and Problems Concerning the Decision of Unconstitutionality on Apportionment for Members of the Diet), 617 Juristo 43 (1976), Professor Abe, another leading constitutional law scholar, states that 1 to 2.5 constitutes an "extreme inequality" which violates the electoral equality required by the Constitution. Abe, Ippyo no Kakusa to Ho no moto no Byodo (Variance in the Value of a Vote and Equality under Law), 830 JURISTo 54 (1985). 
dissented, except for Justices Yokoi and Yasuoka, suggested that they might invalidate an election in the future if the situation were not improved. ${ }^{27}$

On December 18, 1983, a month after the Supreme Court handed down the above decision declaring a disparity of 1 to 3.94 to be in a "state of unconstitutionality," an election for Representatives was held on the basis of the rules of apportionment, which, despite the court's warning, ${ }^{28}$ had not been revised. The maximum relative difference in the ratio of the electoral population per Representative between the Fourth District of Chiba and the Fifth District of Hyogo at the time of the election had reached 1 to 4.40 . Consequently, voters in twenty-one electoral districts challenged the election in four high courts in Hiroshima, Osaka, Tokyo, and Sapporo. All of the courts, while declaring the rules of apportionment unconstitutional, struck down the suits by resorting to the technique of the circumstance decision. The voters immediately appealed to the Supreme Court. In July 1985, however, the Supreme Court affirmed the lower courts' decisions and vacated the petition to nullify the election. The opinion of the Court can be summarized as follows:

(1) The maximum relative difference in the ratio at the time of the 1983 election had reached a degree that violated the constitutional requirement of electoral equality;

(2) the revision to correct the inequality had not been made within a reasonable period of time demanded by the Constitution; and

(3) although the election is declared invalid in the text of the judgment, the petition to nullify it is vacated according to the general principle of law implied in the circumstance decision of Article 31, section 1, of the Administrative Case Litigation Act. ${ }^{29}$

The above opinion is basically a repetition of the Grand Bench decision of 1976. It is noteworthy, however, that the opinion was accompanied by a concurring opinion of Justices Terada, Kinoshita, Itoh, and Yaguchi, which, in opposing the repeated use of the circumstance decision, suggested the possibility of handing down a decision that would make an election prospectively invalid after the lapse of a certain period of time (the so-called Keikoku-Hanketsu prospective invalidation technique, which declares a warning of unconstitutionality in the decision)..$^{30}$ The dissenting opinion of Justice Taniguchi, which insisted that the election be invalidated immediately, ${ }^{31}$ and the separate concurring opinion of Justice Kidoguchi, which expressed agreement with both possibilities mentioned above, ${ }^{32}$ are also noteworthy. With respect to the possibility of using the technique of prospective

27. 37 Minshú at $1272-73$ (Dando, J., dissenting); id. at 1286-87 (Nakamura, J., dissenting); id. at 1287 (Taniguchi, J., dissenting); id. at 1301 (Kidoguchi, J., dissenting).

28. See supra note 27.

29. 39 Minshū 1100.

30. Id. at 1125-26 (Terada, Kinoshita, Itoh and Yaguchi, J., concurring).

31. Id. at 1133-34 (Taniguchi, J., dissenting).

32. Id. at 1127 (Kidoguchi, J., concurring). 
invalidation, the concurring opinion of Justices Terada, Kinoshita, Itoh, and Yaguchi states as follows:

Since the validity of an election is judged in light of all those factors pointed out by the majority opinion, we may have to invalidate an election if it is held based on apportionment rules which have not been revised at all. Should we find it inappropriate to immediately nullify the election, it is not impossible to hand down a judgment making it prospectively invalid after the lapse of a certain period of time. ${ }^{33}$

Under the influence of this decision and of popular sentiment strongly critical of the Diet's negligence, revision of the rules of apportionment for members of the House of Representatives was narrowly realized for the third time in May 1986. This effort, known as the plan of "eight plus, seven minus," was so perfunctory that it simply allocated one seat each to eight grossly disadvantaged districts while depriving seven extremely favored districts of one seat each. As a result, even immediately after the revision, the maximum relative difference in the ratio of electoral population per Representative between districts was still 1 to 2.99 . In light of the still rapidly changing social conditions in Japan, it is only a matter of time before further serious inequality arises in the value of a vote between districts.

\section{V \\ Imbalance in Apportionment and the Judicial Remedy}

In Japan, all reapportionment suits, including those mentioned above, were brought under Article 204 of the Public Officials Election Act, which gives all voters standing to file suit in a court of law in order to contest the validity of an election. This provision, however, was originally designed to nullify an illegally enforced election and to order a new election held. It is evident that the legislators did not have reapportionment cases in mind when they enacted Article 204, for under the provision, if an election is found invalid by the Court, a new election must be held within forty days from the day the challenged election has been invalidated. ${ }^{34}$ When an election is nullified on the grounds that the apportionment law on which the election was based is unconstitutional, the law must be revised and made constitutional before a new election is held. ${ }^{35}$ Also, considering that Article 34, section 6, requires the public announcement of an election eighteen days before an election for Councillors and fifteen days before an election for Representatives, it becomes utterly impossible to revise the rules of apportionment within the periods fixed by Article 34, section 1, which are twenty-two days in the case of Councillor elections and twenty-five days in the case of Representative elections, after subtracting the period of public announcement.

33. Id. (Tarada, Kinoshita, Itoh, and Yaguchi, J., concurring).

34. Public Officials Election Act, art. 34, §1.

35. Id. art. 204, § 1 . 
The Supreme Court has nevertheless agreed to decide reapportionment cases on the merits. The Grand Bench decision of April 14, 1976, for example, stated the following:

The above suit is the only action whereby voters can contest the validity of an election under the present system, and there is no other explicit opportunity in the existing laws for the voters to ask the Court for revision of the Public Officials Election Act on the ground that it is unconstitutional. In light of the constitutional requirement that there should be means to correct, and provide a remedy for, governmental acts which invade the fundamental rights of the people, it is not proper to interpret the above provision as precluding voters from contesting the validity of an election on the grounds that the apportionment law on which it is based is unconstitutional. ${ }^{36}$

The stand taken by the Court, with which the great majority of Japanese constitutional lawyers agree, is that decisions in reapportionment suits brought under Article 204 should not be unreasonably evaded. Since there is no other explicit means in the Constitution or in existing statutes for voters to contest the constitutionality of apportionment rules, there should be a judicial remedy when voters' rights to electoral equality guaranteed by the Constitution are violated. ${ }^{37}$

In fact, however, an awkward situation will inevitably arise if an election is judged invalid, for Article 204 requires that a new election be held within forty days. If, as a result of a court's decision to invalidate the election, Diet members in the affected electoral district would be disqualified and lose their seats as legislators, reapportionment for the district would have to be made without proper representation from their district. Furthermore, if the decision is interpreted so as to affect all electoral districts throughout the nation, all members of the affected House would be disqualified, which would make it impossible for the Diet to revise the apportionment law in question.

Apportionment for Diet members is a question peculiarly political in nature, and one with which the judiciary does not wish to be involved, if at all possible. In 1946, United States Supreme Court Justice Felix Frankfurter pointed out in Colegrove v. Green that "Courts ought not to enter this political thicket."38 In Japan, when a suit was brought challenging the validity of the 1962 election for members of the House of Councillors to be elected from local districts, the Japanese Supreme Court, apparently under the influence of Reynolds $v$. Sims, chose to adopt the theory of legislative discretion without reverting to the "political question doctrine."39 As mentioned above, however, the Court, emphasizing the peculiarities and uniquenesses of the House of Councillors, ${ }^{40}$ concluded that a maximum relative difference of 1 to 4 in the ratio of the electoral population per Councillor did not constitute an

36. 30 Minshū at 251-52.

37. Id.

38. 328 U.S. 549,556 (1946).

39. 18 Minshū at 272-73.

40. For an explanation of the "peculiarities and uniquenesses of the House of Councillors," see 37 Minshū at 349-51. 
"extreme inequality" in violation of the Constitution, thus skillfully evading a constitutional judgment. ${ }^{41}$

On April 14, 1976, the Court finally declared unconstitutional the apportionment rules for Representatives, under which the maximum relative difference of the electoral ratio had reached 1 to $4.94 . .^{42}$ In that case, however, knowing that it was impossible for the Diet to reapportion and have a new election held within the period prescribed by Article 204 of the Public Officials Election Act, the Court did not nullify the election itself, but instead handed down a circumstance decision, invoking the spirit of Article 31, section 1, of the Administrative Case Litigation Act. ${ }^{43}$

The Court must have expected that the Diet would voluntarily revise the apportionment law should it be declared unconstitutional. Expecting the Diet to live up to the Court's expectations turned out to be excessively optimistic, however, for the ruling Liberal Democratic Party had been receiving its main support from the rural areas. In fact, even in the face of the 1976 Grand Bench decision, the Diet did not dare try to take sweeping remedial measures, but only made two minor revisions to barely evade a judgment of unconstitutionality. Needless to say, it is impossible to keep pace with the recent rapid shifts in the population by means of such perfunctory measures. Despite the above two revisions, the maximum disparity between districts at the time of the 1983 election for members of the House of Representatives had reached as much as 1 to 4.40 , and the Court, on July 17, 1985, while declaring the election invalid, again decided to vacate a petition to nullify the election by resorting to the technique of the circumstance decision.

There is no denying that the people's confidence in the judiciary will be greatly impaired if the Court repeatedly resorts to the circumstance decision to avoid nullifying an election simply because a nullification would give rise to uncontrollable governmental confusion. However, the Court can hardly be considered unreasonable in hesitating to hand down a decision to nullify the election, because such a decision would unmistakably bring about chaos in government. Although it has given voters standing to file suits contesting the constitutionality of the rules of apportionment under Article 204, the Japanese Supreme Court has since been in a dilemma whether to repeat the technique of the circumstance decision or to nullify the election resolutely, whatever the consequences.

It is noteworthy that five Justices wrote concurring opinions in the Grand Bench decision of 1985, suggesting the possibility of handing down a decision to make an election prospectively invalid. It is conceivable that they have learned about this procedure from the West German Federal Constitutional Court technique of declaring a warning of unconstitutionality in a decision. As indicated above, this type of decision declares legislation unconstitutional, but provides that the declaration will take effect only after a certain period of

41. 18 Minshū 273 .

42. 30 Minshū 223 .

43. Administrative Case Litigation Act, supra note 21. 
time has elapsed. This technique was used in a famous West German reapportionment case ${ }^{44}$ in order to give the Bundestag time to revise the apportionment law while at the same time holding it responsible for a solution.

VI

\section{Conclusion}

In Reynolds $v$. Sims ${ }^{45}$ the United States Supreme Court established the principle of "one person, one vote" by affirming the lower court's decision, which had issued an injunction to restrain a state from holding an election based on an unconstitutional apportionment law, and ordered the state to abide by a temporary apportionment plan the court imposed. Unlike the United States Supreme Court, which has equity powers, the Japanese Supreme Court has long been under the influence of the Continental European legal tradition, and is thus considered unable to take such active measures as those taken by its American counterpart in Reynolds. There are no laws empowering Japanese courts to issue an injunction or mandamus; to be sure, Japan has traditionally been a country of legal positivism, and judges therefore hesitate to take any active measures without a statutory basis. The 1947 Constitution, however, adopted the Anglo-American judicial concept and vested the courts of law with the power to determine the constitutionality of legislation. With that power, the Japanese courts have, in fact, occasionally performed a lawmaking function.46 Calling attention to that fact, some Japanese legal scholars write that it is unreasonably circumspect for the Court to use repeatedly the circumstance decision method. These commentators suggest that the Court may restrain the election commission from holding an election based on unconstitutional apportionment rules, and instead order it to hold an election based on new rules the Court imposes, unless the Diet revises them. ${ }^{47}$ At the moment, none of the Supreme Court Justices goes so far as to support this idea, but, as mentioned above, five Justices wrote concurring opinions in the 1985 Grand Bench decision in which they opposed repeating the circumstance decision technique a third time, and instead suggested the possibility of handing down a decision of prospective invalidation to give the Diet a little more time than the forty-day period provided in Article 34, section 1, of the Public Officials Election Act. Although the Japanese Supreme Court undeniably has been much influenced by its American counterpart, there are still many basic differences between the two courts in their attitudes toward reapportionment cases.

44. BVerfGE (Federal Constitutional Court Decisions) 16, 130 (1963).

45. 377 U.S. 533 (1964).

46. Tanaka, Teisu Haibun Fubyodo ni Taisuru Shiho-teki Kyusai (Judicial Remedy for Imbalance in the Apportionment of Diet Members), 830 JuRisto 41, 46 (1985).

47. Takahashi, Teisu Fukinko Iken Hanketsu no Mondaiten to Kongo no Kadai (Problems and Solutions Concerning the Decision of Unconstitutionality on Apportionment of Diet Members), 844 JURISTO 29 (1985); Tanaka, supra note 46 , at 42 . 
Even if the Court followed the suggestion of the concurring Justices and handed down a decision of prospective invalidation in the future, is there any guarantee that the Diet would respond favorably to the decision? On this point, the Japanese courts may obtain guidance by reviewing reapportionment decisions of the West German Federal Constitutional Court.

In West Germany, a suit was filed with the Federal Constitutional Court, challenging the validity of the 1961 election for members of the Bundestag on the ground that the election had been held based on an apportionment law that violated the Basic Law of West Germany. The Federal Constitutional Court handed down a decision of prospective invalidation that held that the election would be invalid unless the Bundestag reapportioned by the end of the 1965 legislative session. ${ }^{48}$ Of course, had the Constitutional Court nullified the election at once, the Bundestag, which consisted of members elected under the election in question, would have ceased to exist, making it impossible to revise the apportionment law. That is why West Germany's Constitutional Court resorted to the technique of prospective invalidation instead of invalidating the election at once. The West German Federal Constitutional Court is vested with the means to ensure the enforcement of its own decisions; for example, it can draw up an apportionment plan under Article 35 of the Federal Constitutional Court Act. ${ }^{49}$ Nevertheless, the Court hesitated to do more than make the decision discussed above because it did not want to be involved in the complex and burdensome problem of reapportionment, nor did it want to confront the legislature on this issue. The Bundestag, however, responding to the decision, corrected the imbalance in question by revising the apportionment law in February 1964.50

Yet, it remains questionable whether the Japanese Diet would respond like its German counterpart if the Supreme Court of Japan hands down a decision of prospective invalidation, giving the Diet time to revise the rules of apportionment. Nevertheless, it is possible that the Supreme Court may hand down a decision of prospective invalidation if the imbalance between districts in the ratio of the electoral population per Diet member reaches a constitutionally intolerable degree in the near future.

48. See BVerfGE 16, supra note 44.

49. "The Federal Constitutional Court may in its decision state who will execute it; it can also regulate the type and method of execution in each individual case." Federal Constitutional Court Act, art. 35.

50. BGBI (Federal Gazette) 1,61 (1964). 